\title{
Optimisation of Transplant Age in Combination with Dark-chilling to Enhance the Biological Quality of Broccoli Cultivated in Summer
}

\author{
Aneta GRABOWSKA ${ }^{1}$, Agnieszka SĘKARA ${ }^{1 *}$, Andrzej KALISZ ${ }^{1}$, \\ Edward KUNICKI ${ }^{1}$, Renata WOJCIECHOWSKA ${ }^{2}$, Tomáš KOPTA ${ }^{3}$ \\ ${ }^{1}$ University of Agriculture in Krakow, Faculty of Biotechnology and Horticulture, Department of Vegetable and Medicinal Plants, 29 Listopada \\ 54,31-425Kraków,Poland; a.grabowska@ogr.ur.krakow.pl; a.sekara@ur.krakow.pl (*corresponding author); \\ a.kalisz@ur.krakow.pl; ekunicki@ogr.ur.krakow.pl \\ ${ }^{2}$ University of Agriculture in Krakow, Faculty of Biotechnology and Horticulture, Department of Botany and Plant Physiology, \\ 29 Listopada 54,31-425Kraków, Poland; rwojciechowska@ogr.ur.krakow.pl \\ ${ }^{3}$ Mendel University in Brno, Faculty of Horticulture, Department of Vegetable Science and Floriculture, \\ Valtická337, 69144 Lednice, Czech Republic; tomas.kopta@mendelu.cz
}

\begin{abstract}
Under field conditions, crops are exposed simultaneously to more than one environmental stress factor. Controlled abiotic stress applied at the transplant stage can be used as a tool for inducing stress memory, improving stress tolerance after transplanting, and enhancing the nutraceutical value of the yield. The aim of present study was to determine the effect of darkchilling at $2{ }^{\circ} \mathrm{C}$ for 1 and 2 weeks on the tolerance of broccoli seedlings of various ages against adverse conditions in the field and the chemical composition of the inflorescences. Two separate planting programmes were undertaken in the summer. In general, planting delay by about 1 month resulted in an increase in dry weight of about 3\%, ascorbic acid (38\%), soluble sugars (18\%), K (14\%), P (13\%), Zn (12\%), Fe (8\%), and Mn (9\%) in broccoli inflorescences. Planting of young, 4-week-old seedlings resulted in higher ascorbic acid content in broccoli inflorescences of about $15 \%$, soluble sugars (7\%), $\mathrm{K}(5 \%), \mathrm{P}(6 \%), \mathrm{Mg}(4 \%)$, $\mathrm{Na}(11 \%)$, and $\mathrm{Zn}(3 \%)$ in broccoli inflorescences as compared to 10-week-old ones. Chilling of seedlings for two weeks caused an increase in dry weight in broccoli inflorescences of about $6 \%$, ascorbic acid (15\%), soluble sugars (12\%), K (2\%), P (2\%), Mg (5\%), $\mathrm{Zn}(3 \%), \mathrm{Fe}(4 \%)$, and $\mathrm{Mn}(6 \%)$ as compared to the non-chilled control. The results indicated that the age of the seedlings and dark-chilling influenced the level of chemicals related to taste and biological value of broccoli inflorescences in a complex way. There was no general superiority or interaction of any of the experimental factors affecting all health-related compounds. Dark-chilling can be considered as a practice of broccoli seedling management before transplanting, positively affecting some yield parameters through stress memory induction.
\end{abstract}

Keywords: Brassica oleracea var. italica; chemical compounds; inflorescences; stress memory

optimal growth temperature of about $14^{\circ} \mathrm{C}$, and is commonly produced in Central Europe for spring and autumn harvesting. High temperatures in summer limit

\section{Introduction}

Brassica crops are often used as a research model in plant science as a consequence of the dietetic and pharmacological importance of their metabolites (Jahangir et al., 2009). Broccoli production has risen in the EU and USA over the past several decades (FAO, 2016). A constant supply of fresh broccoli inflorescences is necessary to meet the strict requirements of consumers, who prefer foods that have been produced locally, in their own region (Xie et al., 2016). Broccoli is a typical moderate climate vegetable with an broccoli production because of their direct effect on head quality, although Grabowska et al. (2013) proposed the use of broccoli seedlings of different ages in combination with dark-chilling to develop stress tolerance and improved yield and quality in summer crops in the temperate climatic zone. Low temperature is a common factor determining the beginning of the generative stage of development in broccoli, so its application to seedlings of different ages affected their morphology i.e. market quality of inflorescences. The scientific background of this phenomenon is stress memory, initiated by the application 
of stress during early stages of plant development that affect the plant's tolerance to different stressors acting in subsequent phases of growth (Pastori and Foyer, 2002). The latest research shows that the low-temperature dark storage of seedlings of many vegetable species preserves their market quality (Grabowska et al., 2014; Sato et al., 2004). Stress memory in plants remains insufficiently described with respect to biochemical and physiological mechanisms. It is known that many primary and secondary metabolites and minerals are involved in stress memory. In the case of cultivated crops this phenomenon can affect the yield as a consequence of qualitative and/or quantitative changes in metabolite production (Bruce et al., 2007; Jahangir et al., 2009; Kalisz et al., 2014, 2015).

Broccoli is highly recommended as a dietary component owing to the health protective effects of its primary and secondary metabolites. Sugars and organic acids, which affect the taste of broccoli, are the main compounds detected by consumers (Rosa et al., 2001). Sugars provide energy for the intensively growing and respiring inflorescences and also provide $\mathrm{C}$ skeletons for the production of secondary metabolites, among them the major aliphatic glucosinolate, methionine-derived glucoraphanin, and its derivate sulforaphane, which has well-documented anti-cancer properties (Jeffery and Araya, 2009). Moreover, soluble sugars are involved in the stress response and are related to important changes in reactive oxygen species balance (Couée et al., 2006). Ascorbic acid is a component of the antioxidant defence system, and its synthesis is heavily reliant on stress during plant development, harvest and storage (Raseetha et al., 2013). Excessive stress triggers the initiation of the antioxidative system, whereby ascorbic acid scavenges hydrogen peroxide and then regenerates in the presence of glutathione via the ascorbate-glutathione cycle (Rogers, 2012). An adequate supply of mineral nutrients is integral for the maintenance of photosynthetic electron transport and carbon fixation and utilization under stress conditions. For example $\mathrm{K}$ and $\mathrm{Zn}$ interfere with the NADPH-oxidizing enzyme, providing additional protection against stress. Calcium is responsible for chilling-induced stomatal closure, and increases plants' tolerance to low temperatures by maintaining a high water potential and protection against dehydration (Cakmak, 2008). There is some evidence that the distribution and accumulation of nutrients among the organs of chilling-tolerant Brassica species is significantly affected by chilling stress (Taspinar et al., 2009).
The main hypothesis of this study assumed that it is possible to combine the effect of the age of broccoli seedlings and chilling duration to imprint the stress memory, which improves the quality of broccoli inflorescences by increasing biologically active components. The effect of chilling applied in the juvenile phase on the chemical quality of inflorescences is discussed in relation to stress memory in subsequent stages of development during summer planting.

\section{Materials and Methods}

\section{Plant material and experimental design}

The material under research was broccoli (Brassica oleracea L. var. italica Plenck) 'Monaco' $F_{1}$ (Syngenta), a medium late cultivar designed for summer-autumn harvesting. The experiment was carried out at the University of Agriculture in Krakow, Poland, from 2008 to 2010. The seedlings were grown in a greenhouse, in multipots PV 96 (VEFI, Drammen, Norway) containing standard peat substrate. The experiment included three factors (Table 1): the planting date, the age of the seedlings $(4,6,8$, and 10 weeks), and the dark-chilling treatment ( 1 or 2 weeks at $2{ }^{\circ} \mathrm{C}, 0$ - non-chilled control). The experimental station was located near Krakow, South Poland $\left(50^{\circ} 04^{\prime} \mathrm{N}\right.$, $\left.19^{\circ} 51^{\prime} \mathrm{E}\right)$ in a zone of humid continental climate (Dfb) according to Köppen's classification, on soil classified as Fluvic Cambisol (Humic) according to the classification of the Food and Agriculture Organization of the United Nations (FAO, 2006). The experiment was arranged in a random block design, with four replicates, and 30 plants per treatment, at a spacing of $67.5 \times 40 \mathrm{~cm}$. The agronomic treatments were applied in accordance with the requirements of the broccoli; the fertilization and meteorological conditions were described by Grabowska $e t$ al. (2014). During the first period of cultivation $\left(1^{\text {st }}\right.$ planting date) the mean air temperature was 17.2, 17.2 and $17.4^{\circ} \mathrm{C}$ and during the second ( $2^{\text {nd }}$ planting date) it was $15.0,15.3$, and $15.4{ }^{\circ} \mathrm{C}$, in 2008, 2009 and 2010 respectively. The harvest dates are presented in Table 1.

Inflorescences were harvested with a floral stem, and the length of the stem depended on the inflorescence diameter: the ratio between the floral stem and the diameter of the head was approximately 1:2. Ten inflorescences collected from $1^{\text {st }}$ and $2^{\text {nd }}$ date of planting in the middle of the harvesting period provided the analytical material.

Table 1. Planting date of broccoli seedlings of different age, dark-chilled for 1 or 2 weeks

\begin{tabular}{|c|c|c|c|c|c|}
\hline \multirow{3}{*}{$\begin{array}{l}\text { Planting } \\
\text { date }\end{array}$} & \multirow{3}{*}{$\begin{array}{l}\text { Age of seedlings } \\
\text { (weeks) }\end{array}$} & \multirow{3}{*}{$\begin{array}{l}\text { Chilling duration } \\
\text { (weeks) }\end{array}$} & \multicolumn{3}{|c|}{ Year of the experiment } \\
\hline & & & 2008 & 2009 & 2010 \\
\hline & & & \multicolumn{3}{|c|}{ Planting date } \\
\hline \multirow{3}{*}{$1^{\mathrm{st}}$} & \multirow{3}{*}{$4,6,8$, and 10} & 0 & 17 Jun & 27 Jun & 18 Jun \\
\hline & & 1 & 25 Jun & 02 Jul & 26 Jun \\
\hline & & 2 & 02 Jul & 09 Jul & 03 Jul \\
\hline \multirow{4}{*}{$2^{\text {nd }}$} & \multirow{3}{*}{$4,6,8$, and 10} & 0 & $17 \mathrm{Jul}$ & $16 \mathrm{Jul}$ & $15 \mathrm{Jul}$ \\
\hline & & 1 & $25 \mathrm{Jul}$ & $23 \mathrm{Jul}$ & $23 \mathrm{Jul}$ \\
\hline & & 2 & 01 Aug & $30 \mathrm{Jul}$ & $30 \mathrm{Jul}$ \\
\hline & & & \multicolumn{3}{|c|}{ Harvest date } \\
\hline $1^{\text {st }}$ & & & $29 \mathrm{Jul}-01 \mathrm{Oct}$ & 07 Aug - 24 Sep & 12 Aug - 20 Sep \\
\hline $2^{\text {nd }}$ & & & $17 \mathrm{Sep}-12 \mathrm{Nov}$ & 16 Sep - 03 Nov & 14 Sep - 22 Oct \\
\hline
\end{tabular}


496

\section{Qualitative analysis and statistical procedures}

The plant material was washed in distilled water and ground. The dry weight (DW) content was determined by drying at $105^{\circ} \mathrm{C}$ until constant weight was obtained, and measured using a Sartorius A120S (Germany) weighing scale. The total soluble sugars were determined using the anthrone method (Yemm and Willis, 1954): plant material was mixed with $80 \%$ ethanol and anthrone reagent, and the absorbance was measured at $625 \mathrm{~nm}$ with a Helios Beta spectrophotometer (Thermo Fisher Scientific Inc., USA). The content of L-ascorbic acid was assessed using the Tillmans method. Plant material was mixed with $\mathrm{CH}_{3} \mathrm{COOH}$, extracted for $30 \mathrm{~min}$ and then titrated with 2.6-dichlorophenolindophenol (Tillman's reagent). Phosphorus was determined using coloured phosphorvanado-molybdenum complex by visible spectrophotometry at $460 \mathrm{~nm}$. Potassium, calcium, magnesium, sodium, manganese, zinc and iron were determined by atomic absorption with a Varian SpectrAA 20 (Varian Techtron Pty, Australia) under standard operating conditions and air/acetylene flame following dry mineralization of 5-g plant samples at $500{ }^{\circ} \mathrm{C}$ in the presence of $20 \%$ nitric acid (Jackson and Qiao, 1992).

For a synthetic description, the data were averaged over the 3 years of the experiment. The results were evaluated statistically by ANOVA in STATISTICA Version 10 (StatSoft Inc., Tulsa, USA), and Tukey's test was used to determine homogeneous groups at $\mathrm{p}<0.05$.

\section{Results and Discussion}

The results of this research showed the possibility to combine the effect of the age of broccoli seedlings and chilling duration to imprint the stress memory, which improve the quality of broccoli inflorescences in summer production. Analysis of variance proved the significant relations among variables with respect to main effects and interactions with the exception of dry weight which was not depended on the age of seedlings (Table 2). High temperatures in the summer season can affect carbon metabolism and the sugar partitioning to inflorescences that is required to maintain the sugar pool and support the high respiratory demands of broccoli inflorescences (Rosa et al., 2001). Comparison of the two planting dates, spaced about one month apart, revealed more stressful conditions in the full summer ( $1^{\text {st }}$ planting date) that were reflected in a lower DW, sugar and ascorbic acid content (Figs. 1, 3, 5). Broccoli from the $2^{\text {nd }}$ planting date, which grew in temperatures close to optimal for this species, were about $38.3 \%$ richer in ascorbic acid in comparison to the $1^{\text {st }}$ planting date (Figs. 5, 6). In the conditions of the present experiment plants of different ages were pre-treated with dark-chilling to induce stress tolerance in future stages of ontogeny. Analysis of the main effects showed that 2 weeks of chilling significantly increased the level of DW, soluble sugars, ascorbic acid (Figs. 1, 3, 5) as well as K, P, Mg, Zn, Fe and Mn (Tables 3, 4) in broccoli inflorescences as compared to the non-chilled control. The effect of one week chilling was not so clear. Taspinar et al. (2009) demonstrated that P, Ca and Mg concentration increased, while $\mathrm{K}$ and Fe decreased in coldresistant kale (Brassica oleracea var. acephala) under chilling temperatures in comparison with control plants. Although the interaction of experimental treatment was significant for all elements, we cannot say whether or not the differences were due to the effect of stress memory in the broccoli plant in the current case.

Grabowska et al. (2013) showed that broccoli inflorescences sourced from 4- and 6-week-old seedlings, both chilled and control, had the best visual quality, while chilling of 8- and 10-week-old seedlings affected in planed and spread shape of inflorescences and non-uniformly shaped flower buds. The present results complement the characterization of inflorescence quality depending on seedling age and chilling treatment with respect to chemical components. Inflorescences that developed from 4- and 6week-old seedlings, chilled for 1 and 2 weeks contained

Table 2. Analysis of variance

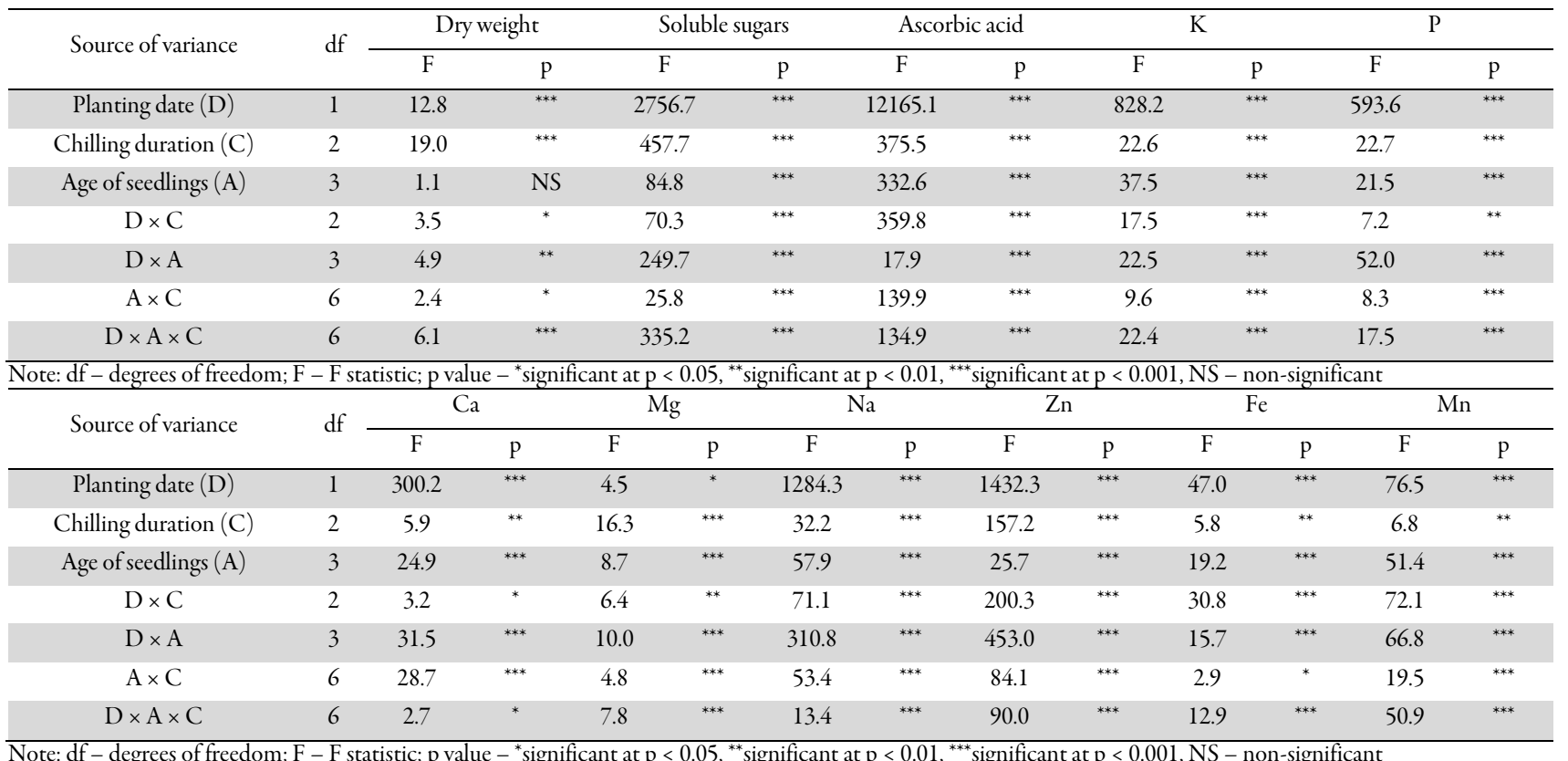

Note: $\mathrm{df}$ - degrees of freedom; F - F statistic; $\mathrm{p}$ value $-{ }^{*}$ significant at $\mathrm{p}<0.05,{ }^{* *}$ significant at $\mathrm{p}<0.01,{ }^{* * *}$ significant at $\mathrm{p}<0.001$, NS - non-significant 
Table 3. Mineral content of broccoli inflorescence cultivated in two dates from seedlings of different age, dark-chilled for 1 or 2 weeks

\begin{tabular}{|c|c|c|c|c|c|c|}
\hline \multirow{2}{*}{$\begin{array}{l}\text { Planting } \\
\text { date }\end{array}$} & \multirow{2}{*}{$\begin{array}{l}\text { Age of seedlings } \\
\text { (weeks) }\end{array}$} & \multirow{2}{*}{$\begin{array}{l}\text { Chilling duration } \\
\text { (weeks) }\end{array}$} & \multicolumn{4}{|c|}{ Content as mean \pm S.E. $\left(\mathrm{mg} 100 \mathrm{~g}^{-1} \mathrm{FW}\right)$} \\
\hline & & & $\mathrm{K}$ & $\mathrm{P}$ & $\mathrm{Ca}$ & $\mathrm{Mg}$ \\
\hline \multirow{12}{*}{$1^{\mathrm{st}}$} & \multirow{3}{*}{4} & 0 & $287 \pm 1.42 c-f$ & $60.4 \pm 0.16 \mathrm{~b}-\mathrm{e}$ & $38.3 \pm 0.67 \mathrm{fg}$ & $16.0 \pm 0.17 \mathrm{~d}-\mathrm{g}$ \\
\hline & & 1 & $292 \pm 1.42 \mathrm{e}-\mathrm{g}$ & $60.1 \pm 0.47 \mathrm{~b}-\mathrm{e}$ & $32.4 \pm 0.22 \mathrm{c}-\mathrm{e}$ & $15.5 \pm 0.31 \mathrm{~b}-\mathrm{f}$ \\
\hline & & 2 & $289 \pm 1.85$ e-f & $63.3 \pm 0.23 \mathrm{e}-\mathrm{h}$ & $30.5 \pm 0.40 \mathrm{a}-\mathrm{d}$ & $16.5 \pm 0.08 \mathrm{f}-\mathrm{g}$ \\
\hline & \multirow{3}{*}{6} & 0 & $284 \pm 0.44$ be & $61.8 \pm 0.49 c-e$ & $33.3 \pm 0.46 c-e$ & $15.0 \pm 0.36$ a-e \\
\hline & & 1 & $289 \pm 0.67 \mathrm{ef}$ & $60.6 \pm 0.28 \mathrm{~b}-\mathrm{e}$ & $32.4 \pm 0.66 c-e$ & $15.9 \pm 0.23 \mathrm{~d}-\mathrm{g}$ \\
\hline & & 2 & $292 \pm 2.29 \mathrm{e}-\mathrm{g}$ & $62.9 \pm 0.16 \mathrm{e}-\mathrm{g}$ & $30.4 \pm 0.16 \mathrm{a}-\mathrm{d}$ & $15.6 \pm 0.32 c-f$ \\
\hline & \multirow{3}{*}{8} & 0 & $282 \pm 1.73 \mathrm{~b}-\mathrm{e}$ & $55.9 \pm 0.09 a$ & $37.2 \pm 0.43 \mathrm{eg}$ & $15.1 \pm 0.09 a-f$ \\
\hline & & 1 & $274 \pm 0.76 \mathrm{a}-\mathrm{c}$ & $57.8 \pm 0.96 \mathrm{a}-\mathrm{c}$ & $41.4 \pm 0.61$ gh & $15.3 \pm 0.11 \mathrm{a}-\mathrm{f}$ \\
\hline & & 2 & $268 \pm 0.59 a$ & $56.5 \pm 1.08 \mathrm{ab}$ & $37.2 \pm 0.12 \mathrm{eg}$ & $14.0 \pm 0.37 \mathrm{a}$ \\
\hline & \multirow{3}{*}{10} & 0 & $271 \pm 2.83 \mathrm{ab}$ & $55.3 \pm 0.08 \mathrm{a}$ & $34.8 \pm 0.10 \mathrm{~d}-\mathrm{f}$ & $14.4 \pm 0.31 \mathrm{a}-\mathrm{c}$ \\
\hline & & 1 & $274 \pm 0.74 a-c$ & $53.9 \pm 2.20 \mathrm{a}$ & $38.9 \pm 1.30 \mathrm{fg}$ & $15.0 \pm 0.30 \mathrm{a}-\mathrm{e}$ \\
\hline & & 2 & $276 \pm 7.84 \mathrm{a}-\mathrm{d}$ & $61.9 \pm 1.15 \mathrm{de}$ & $45.9 \pm 3.71 \mathrm{~h}$ & $16.3 \pm 0.23 \mathrm{e}-\mathrm{g}$ \\
\hline \multirow{12}{*}{$2^{\text {nd }}$} & \multirow{3}{*}{4} & 0 & $314 \pm 2.13 \mathrm{i}-1$ & $68.6 \pm 0.70 \mathrm{ij}$ & $30.4 \pm 0.84 \mathrm{a}-\mathrm{d}$ & $15.1 \pm 0.14 \mathrm{a}-\mathrm{f}$ \\
\hline & & 1 & $325 \pm 0.511$ & $66.4 \pm 0.55 \mathrm{fi}$ & $30.2 \pm 0.37 \mathrm{a}-\mathrm{d}$ & $15.4 \pm 0.31 \mathrm{a}-\mathrm{f}$ \\
\hline & & 2 & $311 \pm 2.24 \mathrm{i}-\mathrm{k}$ & $70.3 \pm 0.76 \mathrm{ij}$ & $26.8 \pm 0.29 \mathrm{ab}$ & $17.4 \pm 0.38 \mathrm{~g}$ \\
\hline & \multirow{3}{*}{6} & 0 & $309 \pm 1.52 \mathrm{~h}-\mathrm{j}$ & $66.2 \pm 0.21 \mathrm{fi}$ & $30.6 \pm 0.25 \mathrm{a}-\mathrm{d}$ & $14.8 \pm 0.24 \mathrm{a}-\mathrm{d}$ \\
\hline & & 1 & $298 \pm 1.65 \mathrm{f}-\mathrm{h}$ & $58.0 \pm 0.82 \mathrm{a}-\mathrm{d}$ & $30.9 \pm 0.26 b-d$ & $14.1 \pm 0.16 \mathrm{ab}$ \\
\hline & & 2 & $306 \pm 0.32 \mathrm{~h}-j$ & $66.5 \pm 0.38 \mathrm{~g}-j$ & $30.5 \pm 0.45 \mathrm{a}-\mathrm{d}$ & $16.0 \pm 0.50 \mathrm{~d}-\mathrm{g}$ \\
\hline & \multirow{3}{*}{8} & 0 & $288 \pm 0.75 \mathrm{~d}-\mathrm{f}$ & $67.6 \pm 0.42 \mathrm{ij}$ & $26.7 \pm 0.33 \mathrm{ab}$ & $16.0 \pm 0.44 \mathrm{~d}-\mathrm{g}$ \\
\hline & & 1 & $326 \pm 2.201$ & $69.8 \pm 0.80 \mathrm{ij}$ & $32.3 \pm 0.17 \mathrm{~cd}$ & $15.5 \pm 0.15 a-f$ \\
\hline & & 2 & $323 \pm 2.18 \mathrm{kl}$ & $70.5 \pm 0.51 j$ & $28.9 \pm 0.33 \mathrm{a}-\mathrm{c}$ & $16.3 \pm 0.23 \mathrm{a}-\mathrm{c}$ \\
\hline & \multirow{3}{*}{10} & 0 & $292 \pm 3.22 \mathrm{e}-\mathrm{g}$ & $67.4 \pm 0.44 \mathrm{~h}-\mathrm{j}$ & $25.9 \pm 0.23 \mathrm{a}$ & $15.8 \pm 0.23 c-f$ \\
\hline & & 1 & $303 \pm 0.89 \mathrm{~g}-\mathrm{i}$ & $67.3 \pm 0.56 \mathrm{~h}-j$ & $30.8 \pm 0.02 \mathrm{~b}-\mathrm{d}$ & $15.5 \pm 0.17 b-f$ \\
\hline & & 2 & $317 \pm 3.51 \mathrm{j}-1$ & $62.3 \pm 1.00 \mathrm{ef}$ & $33.1 \pm 0.12 \mathrm{c}-\mathrm{e}$ & $15.5 \pm 0.13 b-f$ \\
\hline Mean for planting & $1^{\mathrm{st}}$ & & $281 \pm 1.54 \mathrm{~A}$ & $59.2 \pm 0.56 \mathrm{~A}$ & $36.0 \pm 0.81 \mathrm{~B}$ & $15.4 \pm 0.14 \mathrm{~A}$ \\
\hline date & $2^{\text {nd }}$ & & $310 \pm 2.09 \mathrm{~B}$ & $66.7 \pm 0.59 \mathrm{~B}$ & $29.7 \pm 0.37 \mathrm{~A}$ & $15.6 \pm 0.14 \mathrm{~B}$ \\
\hline \multirow{4}{*}{$\begin{array}{l}\text { Mean for age of } \\
\text { seedlings }\end{array}$} & 4 & & $303 \pm 3.57 \mathrm{C}$ & $64.8 \pm 0.96 \mathrm{C}$ & $31.4 \pm 0.86 \mathrm{~A}$ & $16.0 \pm 0.20 \mathrm{~B}$ \\
\hline & 6 & & $296 \pm 2.20 \mathrm{~B}$ & $62.7 \pm 0.74 \mathrm{~B}$ & $31.3 \pm 0.30 \mathrm{~A}$ & $15.2 \pm 0.19 \mathrm{~A}$ \\
\hline & 8 & & $293 \pm 5.61 \mathrm{~B}$ & $63.0 \pm 1.57 \mathrm{~B}$ & $33.9 \pm 1.25 \mathrm{~B}$ & $15.4 \pm 0.20 \mathrm{~A}$ \\
\hline & 10 & & $289 \pm 4.30 \mathrm{~A}$ & $61.4 \pm 1.33 \mathrm{~A}$ & $34.9 \pm 1.62 \mathrm{~B}$ & $15.4 \pm 0.17 \mathrm{~A}$ \\
\hline \multirow{3}{*}{$\begin{array}{l}\text { Mean for chilling } \\
\text { duration }\end{array}$} & 0 & & $291 \pm 2.82 \mathrm{~A}$ & $62.9 \pm 1.04 \mathrm{~B}$ & $32.1 \pm 0.90 \mathrm{~A}$ & $15.3 \pm 0.14 \mathrm{~A}$ \\
\hline & 1 & & $298 \pm 3.96 \mathrm{~B}$ & $62.0 \pm 1.11 \mathrm{~A}$ & $33.7 \pm 0.83 \mathrm{~B}$ & $15.3 \pm 0.12 \mathrm{~A}$ \\
\hline & 2 & & $298 \pm 3.98 \mathrm{~B}$ & $64.3 \pm 0.94 \mathrm{C}$ & $32.9 \pm 1.25 \mathrm{AB}$ & $16.0 \pm 0.21 \mathrm{~B}$ \\
\hline
\end{tabular}

Note: Different letters in columns denote significant differences (Tukey test, $\mathrm{p}<0.05$ ).

significantly higher levels of soluble sugars as compared to the non-chilled control ( $1^{\text {st }}$ date of planting). A similar dependence was found for 10-week-old seedlings chilled for 2 weeks from the $2^{\text {nd }}$ date of planting in terms of DW and soluble sugar content (Figs. 2, 4, 6).

Kaymak et al. (2009), Todorova (2011) and Grabowska et al. (2014) stated that planting of 4-week-old broccoli seedlings resulted in a higher inflorescence yield as compared to 6-, 8- and 10-week old ones. Moreover, Grabowska et al. (2014) showed that high yields can also be achieved from 6and 8-week-old seedlings, with the additional effect of advancing plant maturity and elongating the duration of harvesting. The present results highlight the relationship between transplant age, chilling and the chemical composition of the inflorescences. Those sourced from 6week-old seedlings, both chilled and control, contained the highest amount of ascorbic acid (Fig. 5). In the $2^{\text {nd }}$ date of planting, 2 weeks of chilling significantly increased the ascorbic acid content in broccoli transplanted at 6,8 and 10 weeks as compared to the non-chilled control (Fig. 6). Inflorescences from the $1^{\text {st }}$ date of planting, sourced from 4 - and 6-week-old seedlings chilled for 2 weeks contained the highest amount of soluble sugar. In the $2^{\text {nd }}$ date of planting, 2 weeks of chilling significantly increased the soluble sugar content in broccoli transplanted at 8 and 10 weeks (Fig. 4). These results are consistent with those of Van den Ende and Valluru (2008), who stated that water-soluble sugars are now recognized as crucial compounds for coordinating plant developmental responses when exposed to stress. Moreover, soluble sugars are involved in the response to a number of stresses, and they act as nutrient and metabolite signalling molecules that activate transduction pathways, thus resulting in important modifications of gene expression and proteomic patterns (Valluru and Van den Ende, 2008; Couée et al., 2006).

Regardless of the experimental treatments broccoli inflorescences can be considered as a good source of minerals in the human diet. The pro-health benefits of broccoli have been emphasized in recent literature (Moreno et al., 2006; Vasanthi et al., 2009). The ranges of minerals content in broccoli inflorescences in the conditions of the present experiment were as follows: potassium 268-326, phosphorus 53.9-70.5, calcium 
498

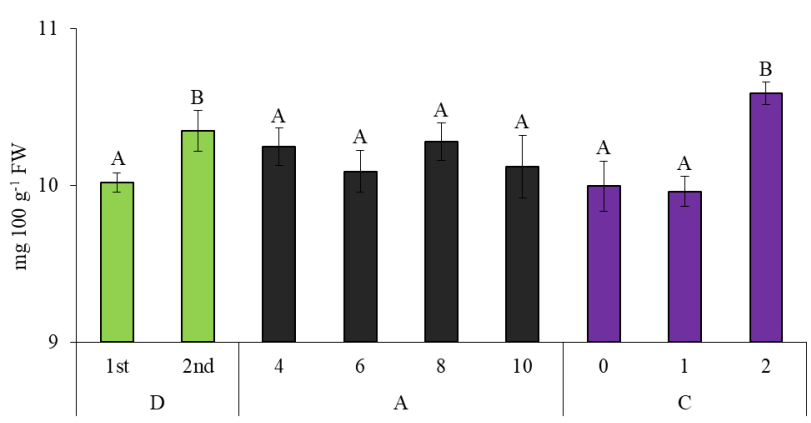

Fig. 1. Dry weight of inflorescences of broccoli $\left(\mathrm{mg} 100 \mathrm{~g}^{-1}\right.$ FW) planted in two dates from seedlings of different age, darkchilled for 1 or 2 weeks, means for D - planting date; A - age of seedlings in weeks, C - chilling duration in weeks. Note: Different letters above the bars of particular colour denote significant differences \pm SE (Tukey test, $\mathrm{p}<0.05$ )

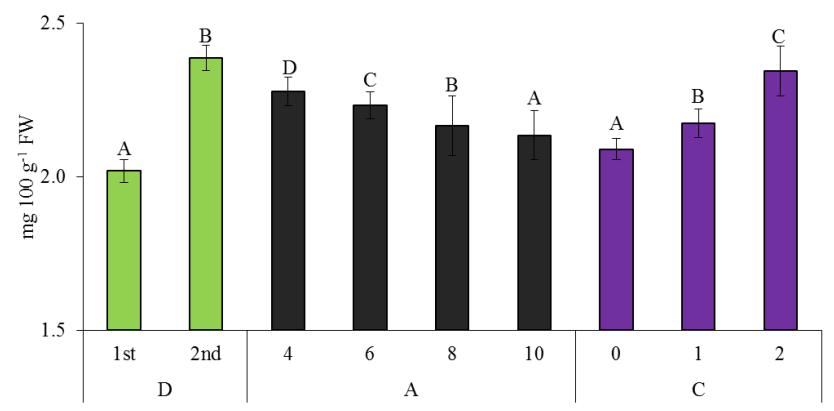

Fig. 3. Soluble sugars in inflorescences of broccoli $\left(\mathrm{mg} 100 \mathrm{~g}^{-1}\right.$ FW) planted in two dates from seedlings of different age, darkchilled for 1 or 2 weeks, means for D - planting date; A - age of seedlings in weeks, $\mathrm{C}$ - chilling duration in weeks. Note: Different letters above the bars of particular colour denote significant differences \pm SE (Tukey test, $\mathrm{p}<0.05$ )

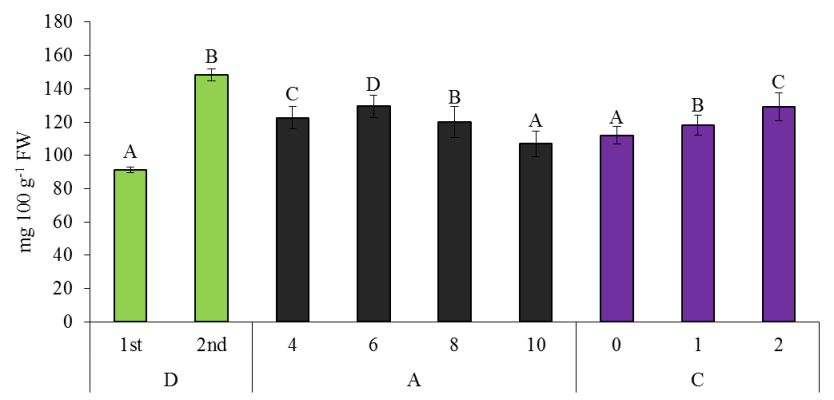

Fig. 5. Ascorbic acid in inflorescences of broccoli (mg $100 \mathrm{~g}^{-1}$ FW) planted in two dates from seedlings of different age, darkchilled for 1 or 2 weeks, means for D - planting date; A - age of seedlings in weeks, C - chilling duration in weeks. Note: Different letters above the bars of particular colour denote significant differences \pm SE (Tukey test, $\mathrm{p}<0.05$ )

26.7-45.9, magnesium 14.1-17.4, sodium 12.4-23.0, zinc $0.56-0.85$, iron 0.64-0.89, and manganese $0.26-0.48 \mathrm{mg} 100 \mathrm{~g}$ ${ }^{1} \mathrm{FW}$ (Tables 3, 4). The mineral composition of ten broccoli cultivars grown in Poland for the autumn harvest was recently described by Kałużewicz et al. (2016). During a oneyear study in north-western Croatia the tested broccoli cultivars achieved higher values of mass, yield, nitrogen,

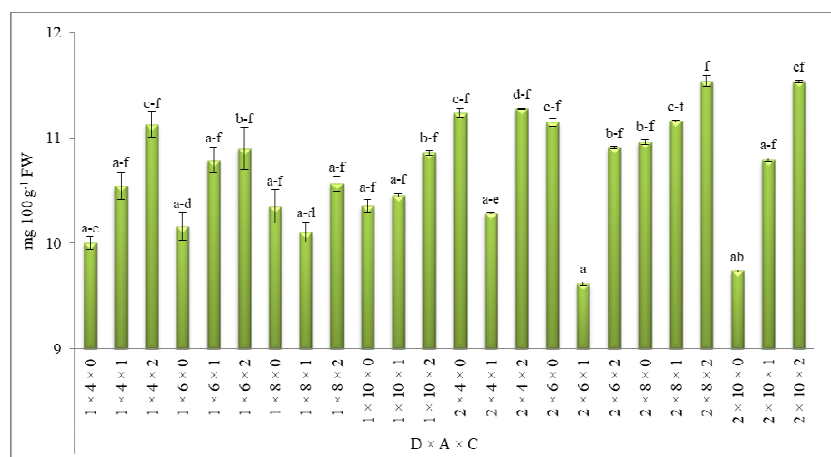

Fig. 2. Dry weight of inflorescences of broccoli (mg $100 \mathrm{~g}^{-1}$ FW) planted in two dates from seedlings of different age, darkchilled for 1 or 2 weeks, interaction D - planting date; A - age of seedlings in weeks, C - chilling duration in weeks. Note: Different letters above the bars denote significant differences \pm SE (Tukey test, $\mathrm{p}<0.05$ )

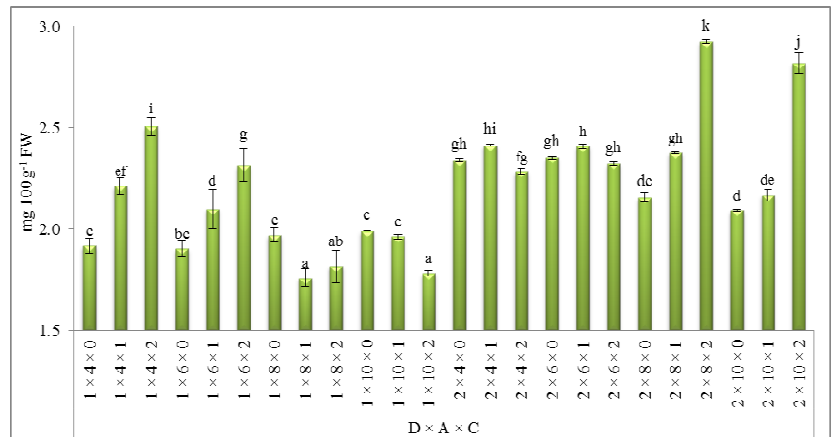

Fig. 4. Soluble sugars in inflorescences of broccoli $\left(\mathrm{mg} 100 \mathrm{~g}^{-1}\right.$ FW) planted in two dates from seedlings of different age, darkchilled for 1 or 2 weeks, interaction D - planting date; A - age of seedlings in weeks, C - chilling duration in weeks. Note: Different letters above the bars denote significant differences \pm SE (Tukey test, $\mathrm{p}<0.05$ )

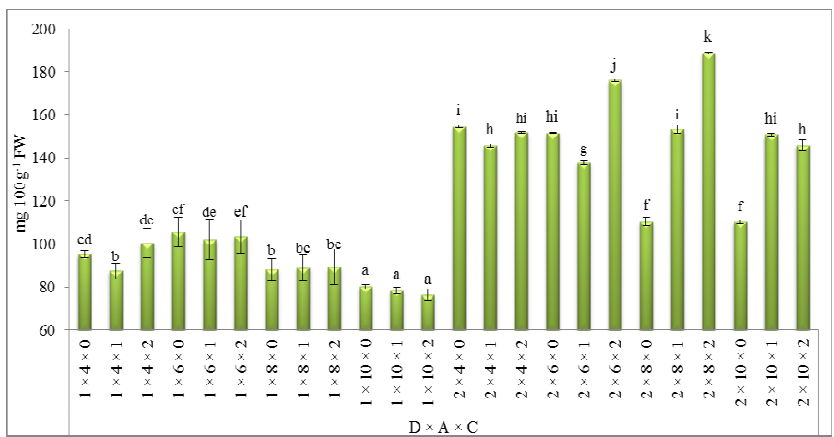

Fig. 6. Ascorbic acid in inflorescences of broccoli (mg $100 \mathrm{~g}^{-1}$ FW) planted in two dates from seedlings of different age, darkchilled for 1 or 2 weeks, interaction D - planting date; A - age of seedlings in weeks, C - chilling duration in weeks. Note: Different letters above the bars denote significant differences \pm SE (Tukey test, $\mathrm{p}<0.05$ )

phosphorus and potassium in the top inflorescence during the summer-autumn growing period, while the calcium content was higher in the spring-summer growing period (Fabek et al., 2012). The interaction of signals conferring stress memory and developmental traits and its influence on crop growth and yield is a priority in programmes for improving plant stress tolerance (Pastori and Foyer, 2002). 
Table 4. Mineral content of broccoli inflorescence cultivated in two dates from seedlings of different age, dark-chilled for 1 or 2 weeks

\begin{tabular}{|c|c|c|c|c|c|c|}
\hline \multirow{2}{*}{$\begin{array}{l}\text { Planting } \\
\text { date }\end{array}$} & \multirow{2}{*}{$\begin{array}{l}\text { Age of seedlings } \\
\text { (weeks) }\end{array}$} & \multirow{2}{*}{$\begin{array}{l}\text { Chilling } \\
\text { duration } \\
\text { (weeks) }\end{array}$} & \multicolumn{4}{|c|}{ Content as mean \pm S.E. $\left(\mathrm{mg} 100 \mathrm{~g}^{-1} \mathrm{FW}\right)$} \\
\hline & & & $\mathrm{Na}$ & $\mathrm{Zn}$ & $\mathrm{Fe}$ & $\mathrm{Mn}$ \\
\hline \multirow{12}{*}{$1^{\mathrm{st}}$} & \multirow{3}{*}{4} & 0 & $19.8 \pm 0.07 \mathrm{~g}$ & $0.69 \pm 0.00 \mathrm{ef}$ & $0.67 \pm 0.01 \mathrm{ab}$ & $0.27 \pm 0.00 \mathrm{ab}$ \\
\hline & & 1 & $23.0 \pm 0.11 \mathrm{i}$ & $0.68 \pm 0.00$ ef & $0.67 \pm 0.01 \mathrm{ab}$ & $0.30 \pm 0.01 \mathrm{a}-\mathrm{f}$ \\
\hline & & 2 & $23.0 \pm 0.43 \mathrm{i}$ & $0.74 \pm 0.00 \mathrm{hi}$ & $0.70 \pm 0.03 \mathrm{a}-\mathrm{c}$ & $0.34 \pm 0.01 \mathrm{e}-\mathrm{i}$ \\
\hline & \multirow{3}{*}{6} & 0 & $19.9 \pm 0.15 \mathrm{gh}$ & $0.65 \pm 0.00 \mathrm{~cd}$ & $0.64 \pm 0.01 \mathrm{a}$ & $0.28 \pm 0.00 \mathrm{a}-\mathrm{c}$ \\
\hline & & 1 & $22.4 \pm 0.08 \mathrm{i}$ & $0.71 \pm 0.00 \mathrm{fg}$ & $0.71 \pm 0.02 \mathrm{a}-\mathrm{c}$ & $0.36 \pm 0.00 \mathrm{~g}-j$ \\
\hline & & 2 & $20.6 \pm 0.20 \mathrm{gh}$ & $0.75 \pm 0.00 \mathrm{~h}-\mathrm{j}$ & $0.80 \pm 0.00 c-f$ & $0.39 \pm 0.01 \mathrm{i}-\mathrm{k}$ \\
\hline & \multirow{3}{*}{8} & 0 & $21.6 \pm 0.00 \mathrm{hi}$ & $0.63 \pm 0.00 b c$ & $0.65 \pm 0.00 \mathrm{a}$ & $0.30 \pm 0.01 \mathrm{a}-\mathrm{f}$ \\
\hline & & 1 & $19.5 \pm 0.14 \mathrm{~g}$ & $0.62 \pm 0.00 \mathrm{~b}$ & $0.66 \pm 0.01 \mathrm{ab}$ & $0.31 \pm 0.00 \mathrm{~b}-\mathrm{f}$ \\
\hline & & 2 & $17.2 \pm 0.14 \mathrm{e}$ & $0.62 \pm 0.00 b$ & $0.68 \pm 0.01 \mathrm{ab}$ & $0.29 \pm 0.01 \mathrm{a}-\mathrm{d}$ \\
\hline & \multirow{3}{*}{10} & 0 & $17.6 \pm 0.13 \mathrm{e}$ & $0.56 \pm 0.00 \mathrm{a}$ & $0.66 \pm 0.02 \mathrm{ab}$ & $0.33 \pm 0.01 \mathrm{~d}-\mathrm{g}$ \\
\hline & & 1 & $14.7 \pm 0.18 \mathrm{~cd}$ & $0.62 \pm 0.00 b$ & $0.72 \pm 0.03 \mathrm{a}-\mathrm{d}$ & $0.37 \pm 0.01 \mathrm{~g}-j$ \\
\hline & & 2 & $12.9 \pm 1.35 \mathrm{ab}$ & $0.67 \pm 0.02 \mathrm{de}$ & $0.86 \pm 0.04 \mathrm{ef}$ & $0.42 \pm 0.02 \mathrm{k}$ \\
\hline \multirow{12}{*}{$2^{\text {nd }}$} & \multirow{3}{*}{4} & 0 & $12.8 \pm 0.03 \mathrm{ab}$ & $0.70 \pm 0.00 \mathrm{fg}$ & $0.76 \pm 0.01 \mathrm{~b}-\mathrm{e}$ & $0.43 \pm 0.01 \mathrm{k}$ \\
\hline & & 1 & $12.4 \pm 0.06 \mathrm{a}$ & $0.69 \pm 0.00 \mathrm{ef}$ & $0.89 \pm 0.01 \mathrm{f}$ & $0.41 \pm 0.01 \mathrm{jk}$ \\
\hline & & 2 & $12.9 \pm 0.13 \mathrm{ab}$ & $0.77 \pm 0.00 \mathrm{j}$ & $0.84 \pm 0.01 \mathrm{ef}$ & $0.42 \pm 0.01 \mathrm{k}$ \\
\hline & \multirow{3}{*}{6} & 0 & $12.9 \pm 0.07 \mathrm{ab}$ & $0.69 \pm 0.00$ ef & $0.82 \pm 0.02 \mathrm{~d}-\mathrm{f}$ & $0.48 \pm 0.001$ \\
\hline & & 1 & $13.3 \pm 0.03 \mathrm{a}-\mathrm{c}$ & $0.63 \pm 0.00 b c$ & $0.72 \pm 0.02 \mathrm{a}-\mathrm{d}$ & $0.26 \pm 0.01 \mathrm{a}$ \\
\hline & & 2 & $14.1 \pm 0.08 \mathrm{bc}$ & $0.76 \pm 0.00 \mathrm{ij}$ & $0.69 \pm 0.01 \mathrm{ab}$ & $0.29 \pm 0.00 \mathrm{a}-\mathrm{d}$ \\
\hline & \multirow{3}{*}{8} & 0 & $19.4 \pm 0.08 \mathrm{fg}$ & $0.82 \pm 0.01 \mathrm{k}$ & $0.70 \pm 0.02 \mathrm{a}-\mathrm{c}$ & $0.30 \pm 0.01 \mathrm{a}-\mathrm{e}$ \\
\hline & & 1 & $13.3 \pm 0.09 \mathrm{a}-\mathrm{c}$ & $0.75 \pm 0.00 \mathrm{ij}$ & $0.68 \pm 0.01 \mathrm{ab}$ & $0.35 \pm 0.01 \mathrm{f}-\mathrm{i}$ \\
\hline & & 2 & $16.4 \pm 0.09 \mathrm{de}$ & $0.75 \pm 0.00 \mathrm{ij}$ & $0.70 \pm 0.01 \mathrm{a}-\mathrm{c}$ & $0.32 \pm 0.01 \mathrm{c}-\mathrm{g}$ \\
\hline & \multirow{3}{*}{10} & 0 & $17.8 \pm 0.42$ ef & $0.85 \pm 0.001$ & $0.85 \pm 0.05$ ef & $0.34 \pm 0.00 \mathrm{e}-\mathrm{h}$ \\
\hline & & 1 & $13.2 \pm 0.19 \mathrm{a}-\mathrm{c}$ & $0.72 \pm 0.00 \mathrm{gh}$ & $0.71 \pm 0.01 \mathrm{a}-\mathrm{c}$ & $0.39 \pm 0.01 \mathrm{~h}-\mathrm{k}$ \\
\hline & & 2 & $17.3 \pm 0.07 \mathrm{e}$ & $0.70 \pm 0.00 \mathrm{fg}$ & $0.71 \pm 0.02 \mathrm{a}-\mathrm{d}$ & $0.36 \pm 0.00 \mathrm{~g}-j$ \\
\hline \multirow{2}{*}{$\begin{array}{c}\text { Mean for } \\
\text { planting date }\end{array}$} & $1^{\mathrm{st}}$ & & $19.3 \pm 0.53 \mathrm{~B}$ & $0.66 \pm 0.01 \mathrm{~A}$ & $0.70 \pm 0.01 \mathrm{~A}$ & $0.33 \pm 0.01 \mathrm{~A}$ \\
\hline & $2^{\text {nd }}$ & & $14.7 \pm 0.39 \mathrm{~A}$ & $0.74 \pm 0.01 \mathrm{~B}$ & $0.76 \pm 0.01 \mathrm{~B}$ & $0.36 \pm 0.01 \mathrm{~B}$ \\
\hline \multirow{4}{*}{$\begin{array}{c}\text { Mean for age of } \\
\text { seedlings }\end{array}$} & 4 & & $17.3 \pm 1.15 \mathrm{~B}$ & $0.71 \pm 0.01 \mathrm{C}$ & $0.76 \pm 0.02 \mathrm{~B}$ & $0.36 \pm 0.01 \mathrm{C}$ \\
\hline & 6 & & $17.2 \pm 0.93 \mathrm{~B}$ & $0.70 \pm 0.01 \mathrm{~B}$ & $0.73 \pm 0.01 \mathrm{~B}$ & $0.34 \pm 0.02 \mathrm{~B}$ \\
\hline & 8 & & $17.9 \pm 0.64 \mathrm{C}$ & $0.70 \pm 0.02 \mathrm{~B}$ & $0.68 \pm 0.01 \mathrm{~A}$ & $0.31 \pm 0.00 \mathrm{~A}$ \\
\hline & 10 & & $15.6 \pm 0.54 \mathrm{~A}$ & $0.69 \pm 0.02 \mathrm{~A}$ & $0.75 \pm 0.02 \mathrm{~B}$ & $0.37 \pm 0.01 \mathrm{C}$ \\
\hline \multirow{3}{*}{$\begin{array}{c}\text { Mean for chilling } \\
\text { duration }\end{array}$} & 0 & & $17.7 \pm 0.63 \mathrm{~B}$ & $0.70 \pm 0.02 \mathrm{~B}$ & $0.72 \pm 0.02 \mathrm{~A}$ & $0.34 \pm 0.01 \mathrm{~A}$ \\
\hline & 1 & & $16.5 \pm 0.87 \mathrm{~A}$ & $0.68 \pm 0.01 \mathrm{~A}$ & $0.72 \pm 0.01 \mathrm{~A}$ & $0.34 \pm 0.01 \mathrm{~A}$ \\
\hline & 2 & & $16.8 \pm 0.72 \mathrm{~A}$ & $0.72 \pm 0.01 \mathrm{C}$ & $0.75 \pm 0.01 \mathrm{~B}$ & $0.36 \pm 0.01 \mathrm{~B}$ \\
\hline
\end{tabular}

Note: Different letters in columns denote significant differences (Tukey test, $\mathrm{p}<0.05$ ).

Consumers' demands are focused on food rich in prohealth elements and compounds. Future research into the mechanisms behind stress-memory induction and maintenance during broccoli ontogeny could lead to an understanding of the metabolome regulation of the variations in the chemical composition of the crop. From a wider perspective, this information could contribute to a more sustainable and environmentally friendly method of food production.

\section{Conclusions}

High and low temperature stress is one of the important environmental factors that may affect broccoli yielding. The precise application of chilling stress in the juvenile phase of broccoli development resulted in stress memory imprinting in plants and modified the chemical composition of inflorescences. This effect seems to be significant but inconsistent with respect to investigated chemical compounds and minerals because of the different physiological functions they undertake. Generally, darkchilling for a period of 2 weeks can be applied for effective storage and transportation of 4-10 week-old broccoli seedlings. This practice allows simultaneously increasing pro-health chemical compounds level in broccoli inflorescences during summer cultivation.

\section{Acknowledgements}

This work was supported by the Ministry of Science and Higher Education in Poland, project No. N N310 309434.

\section{References}

Bruce TJA, Matthes MC, Napier JA, Pickett JA (2007). Stresful "memories" of plants: evidence and possible mechanisms. Plant Science 173(6):603-608.

Cakmak I (2008). Role of mineral nutrients in tolerance of crop plants to 
500

environmental stress factors. In: Imas P, Price MR (Eds). Fertigation: optimizing the utilization of water and nutrients, International Symposium on Fertigation. Beijing, Chinapp 35-48.

Couée I, Sulmon C, Gouesbet G, El Amrani A (2006). Involvement of soluble sugars in reactive oxygen species balance and responses to oxidative stress in plants. Journal of Experimental Botany 57(3):449459.

FabekS, TothN, Radojččć RedovnikovićLI,Herak ĆustićM, Benko B,Žutić I (2012). The effect of nitrogen fertilization on nitrate accumulation, and the content of minerals and glucosinolates in broccoli cultivars. Food Technology and Biotechnology 50(2):183-191.

FAO (2016).FAOSTAT.FAO, Rome, Italy. Retrieved $2018 \mathrm{Feb} 02$ from http://www.fao.org/home/en/.

FAO (2006). World Reference Base for Soil Resources. FAO, Rome, Italy. Retrieved 2017 Oct09 from http://www.fao.org/home/en/.

Grabowska A, Kunicki E, Kalisz A, Wojciechowska R, Leja M, Sękara A (2014). Chilling stress applied to broccoli transplants of different age affects yield of the plants cultivated in summer. Horticultural Science (Prague) 41(2):71-79.

Grabowska A, Sękara A, Bieniasz M, Kunicki E, Kalisz A (2013). Darkchilling of seedlings affects initiation and morphology of broccoli inflorescence. Notulae Botanicae Horti Agrobotanici Cluj-Napoca 41(1):213-218.

Jackson KW, Qiao H (1992). Atomic-absorption, atomic emission, and flameemission-spectrometry. Analytical Chemistry 64:R50-R66.

Jahangir M, Abdel-Farid BI, Kim HK, Choi YH, Verpoorte R (2009). Healthy and unhealthy plants: The effect of stress on the metabolism of Brassicaceae. Environmental and Experimental Botany 67:23-33.

Jeffery EH, Araya M (2009). Physiological effects of broccoli consumption. Phytochemical Reviews 8:283-298.

Kalisz A, Sękara A, Cebula S, Grabowska A, Kunicki E (2014). Impact of low-temperature transplant treatment on yield and quality of caulifflower curds in late spring production. Scientia Horticulturae 176:134142.

Kalisz A, Sękara A, Grabowska A, Cebula S, KunickiE (2015). The effect of chilling stress at transplant stage on broccoli development and yield with elements of modeling. Journal of Plant Growth Regulation 34:532-544.

Katużewicz A, Bosiacki M, Frązzzzak B (2016). Mineral composition and the content of phenolic compounds of ten broccoli cultivars. Journal of Elementology 21(1):53-65.

Kaymak HC, Yarali F, Guvenc I (2009). Effect of transplant age on growth and yield of broccoli (Brassica oleracea var. italica). Indian Journal of Agricultural Sciences 79:972-975.

Moreno DA, Carvajal M, López-Berenguer C, García-Viguera C (2006). Chemical and biological characterisation of nutraceutical compounds of broccoli. Journal of Pharmaceutical and Biomedical Analysis 41(5):1508-1522.
Pastori GM, Foyer CH (2002). Common components, networks, and pathways of cross-tolerance to stress. The central role of "redox" and abscisic acid-mediated controls. Plant Physiology 129(2):460-468.

Raseetha S, Leong SY, Burritt DJ, Oey I (2013). Understanding the degradation of ascorbic acid and glutathione in relation to the levels of oxidative stress biomarkers in broccoli (Brassica oleracea L. italica cv. Bellstar) during storage and mechanical processing. Food Chemistry 138:1360-1369.

Rogers $\mathrm{HJ}$ (2012). Is there an important role for reactive oxygen species and redox regulation during floral senescence? Plant, Cell \& Environment 35(2):217-233.

Rosa E, David M, Gomes MH (2001). Glucose, fructose and sucrose content in broccoli, white cabbage and Portuguese cabbage grown in early and late seasons. Journal of the Science of Food and Agriculture 81:1145-1149.

Sato F, Yoshioka H, Fujiwara T, Higashio H, Uragami A, Tokuda S (2004). Physiological responses of cabbage plug seedlings to water stress during low-temperature storage in darkness. Scientia Horticulturae 101(4):349-357.

Taspinar S, Dumlupinar R, Demir F, Cakmak T, Gülen Y (2009). Determination of chilling temperature effects on nutrient elements composition and distribution in cole (Brassica oleracea L. cv. Acephala) using the WDXRF spectroscopic technique. African Journal of Biotechnology 8:6569-6575.

Todorova $\mathrm{D}$ (2011). Effect of transplant age on the productive behaviors of broccoli Brassica oleracea var. italica Plenck. Plant Science 48:223-226.

Van den Ende W, Valluru R (2008). Sucrose, sucrosyl oligosaccharides, and oxidative stress: scavenging and salvaging? Journal of Experimental Botany 60(1):9-18.

Valluru R, Van den Ende W (2008). Plant fructans in stress environments: emerging concepts and future prospects. Journal of Experimental Botany 59:2905-2916.

Vasanthi HR, Mukherjee S, Das DK (2009). Potential health benefits of broccoli - a chemico-biological overview. Mini-Reviews in Medicinal Chemistry 9(6):749-759.

Xie J, Gao Z, Swisher M, Zhao X (2016). Consumers' preferences for fresh broccolis: interactive effects between country of origin and organic labels. Agricultural Economics 47:181-191.

Yemm EW Willis AJ (1954). The estimation of carbohydrates in plant extracts by anthrone. Biochemical Journal $57: 508-514$. 